\title{
GAYA KOMUNIKASI \\ MODEL PROFESIONAL SZ MANAGEMENT SURABAYA
}

\section{Ulfi Nurfaiza}

Universitas Islam Negeri Sunan Ampel Surabaya

nurfaiza@gmail.com

\begin{tabular}{l}
\hline \hline Article Info \\
\hline \\
Article history: \\
Received 16 August 2018 \\
Accepted 15 September 2018 \\
Published 10 Oktober 2018 \\
\hline
\end{tabular}

\section{Keyword:}

Gaya komunikasi, model profesional, verbal, nonverbal

\section{Abstract}

Penelitian ini membahas tentang Gaya Komunikasi Model Professional SZ Management Surabaya melaui komunikasi secara verbal dan nonverbal. Metode penelitian ini peneliti menggunakan metode deskriptif kualitatif. Tujuan yang ingin dicapai oleh peneliti adalah untuk memahami dan mendeskripsikan gaya komunikasi Model Professional SZ Management Surabaya secara verbal dan nonverbal.

Hasil peneliti ini bahwa, gaya komunikasi model professional secara verbal dapat diketahui melalui penggunaan bahasa sehari hari. Sedangkan melalui nonverbal dapat diketahui melalui ketinggian badan yang berkisaran antara 165 - $170 \mathrm{~cm}$, busana yang sesuai dengan waktu dan situasi setiap model, ekspresi wajah yang memiliki kemampuan fotogenic atau dapat disebut wajah menarik saat di kamera serta kemampuan di bidang (catwalk) kemampuan berjalan berlenggak-lenggok dengan memperagakan busana yang berada di atas panggung dan disaksikan oleh banyak pihak dengan menggunakan sepatu high heels yang berketinggian kisaran $12-15 \mathrm{~cm}$.

\section{Editorial Office:}

Program Studi Ilmu Komunikasi, Fakultas Dakwah dan Komunikasi, UIN Sunan Ampel Surabaya. Jl. Ahmad Yani 117 Surabaya, Jawa Timur, Indonesia.

Email: jurnalilkom@uinsby.ac.id 


\section{Pendahuluan}

Dunia model berkaitan erat dengan dunia fashion. Para Perancang mode fashion akan mengalami kesuksesan dalam produk fashionnya jika mampu bekerjasama dengan para model untuk menjadi peraga busana. Para Perias juga akan terkenal jika mampu bekerjasama dengan sosok model dalam mempromosikan jasa riasnya. Namun, tidak semua model mampu menyukseskan para perancang busana. Hal ini dikarenakan Model adalah seseorang yang dipekerjakan untuk tujuan menampilkan dan mempromosikan pakaian mode atau produk lainnya,iklan atau promosi yang berpose untuk karya seni dengan tujuan menciptakan atau menyampaikan image produk yang diperagakan kepada konsumen. Sehingga menjadi model harus memiliki beberapa persyaratan dengan tujuan mampu mempromosikan pakain dengan baik serta mampu bekerjasama dengan para perancang mode, penata rias dan lain lain.

Seorang Model mampu menunjukkan keberhasilan secara garis besar memang, ditentukan oleh beberapa faktor misalnya keberuntungan, bakat, dan kecantikan fisik. Keberhasilan dalam keberuntungan setiap model dikarenakan beragai perbedaan faktor diantaranya mlai dari faktor keluarga yang dari lahir telah didorong untuk terjun di dunia model, faktor fisik yang mencukupi atau faktor motivasi dalam diri yang tinggi sehingga mendapatkan keberuntungan untuk terjun di dunia model. Adapun bakat dimiliki karena adanya potensi yang terpendam dalam diri seorang model diantaranya karena memiliki kemampuan berjalan model dengan baik, memilik aura wajah fotogenik dan lain lain. Sedangkan kecantikan fisik dapat dimiliki setiap model seperti postur tubuh yang tinggi semampai, kulit bersih, wajah cantik dan lain lain. Terkadang kecantikan fisik dapat dimiliki secara alami akan tetapi adapula yang berusaha hingga melakukan operasi plastic dan menggunakan obat - obat tertentu agar mendapatkan hasil sesuai yang dimiliki seorang model.

Namun, jika hanya mengandalkan hal-hal tersebut maka bisa pula tergeser oleh para pesaing model model hebat lainnya. ${ }^{1}$ Seiring dengan perkembangan zaman, dunia fashion khususnya di Indonesia terus mengalami perubahan yakni memiliki beraneka ragam inovasiinovasi produk fashion terbaru. Seperti contoh produk batik merupakan produk karya Indonesia yang telah lahir hingga puluhan tahun yang lalu namun, kini cukup popular, sangat unggul di dunia fashion dan dapat digunakan dalam situasi apapun diantaranya batik dengan model formal yakni dapat digunakan saat acara-acara formal, batik casual yang digunakan ketika dalam acara santai, batik glamour yang dapat digunakan dalam acara pesta dan batik dengan model lain lain.

Dalam menjalani kariernya, Para model SZ Model Management kota Surabaya berusaha mampu mempertahankan eksistensinya sebagai model yang memiliki berbagai strategi khusus dalam menunjukkan keprofesionalan menjadi sosok model yang mampu bekerjasama dengan orang-orang yang bekerja di bidang fashion serta 
mampu memiliki kredibilitas khusus dari model model lainya. Pada penelitian ini sangat penting untuk mengetahui gaya komunikasi model professional SZ Model Management Surabaya.

Pemilik karya batik di Indonesia telah tersebar diberbagai provinsi bahkan kota maupun kabupaten telah memiliki beranekaragam karya karya batik Indonesia. Dengan keanekaragaman karya batik di bidang fashion tersebut tentu persaingan di bidang bisnis cukup banyak pula. Salah satu cara memasarkan produk tersebut hingga dikenal, diminati dan dikonsumsi oleh konsumen yaitu dengan memanfaatkan jasa model professional sebagai icon produk.

\section{Kajian Pustaka \\ Konsep Komunikasi}

Kebutuhan akan pentingnya komunikasi tidak dapat terlepas dalam melakukan setiap aktivitas sehari-hari. Hingga saat ini kegiatan komunikasi selalu berkembang dengan bertambahnya waktu dan perbedaan budaya. Tanpa melakukan komunikasi dan memahami pentingnya komunikasi sangat sulit jika dipisahkan dalam kehidupan manusia. Secara spontanitas setiap manusia baik yang baru lahir di dunia maupun dewasa dalam kondisi apapun selalu melakukan komunikasi.

Bahwa istilah komunikasi berasal dari Bahasa Inggris yaitu communication yang berasal dari bahasa latin

\footnotetext{
1 Stephen W. LittleJhon \& Karen A.Foss, Teori Komunikasi, (Jakarta:PT,Salemba
}

comminicatio dan bersumber dari communis yang berarti sama, yaitu sama makna. Kesamaan makna ini mengandung pengertian bahwa antara komunikator dan komunikan memiliki persepsi yang sama tentang apa yang sedang dikomunikasikan atau dibicarakan. Pihak komunikator dan komunikan memiliki sikap komunikatif. Sedangkan sifat komunikatif didapatkan jika kedua belah ihak mempunyai sifat empati. ${ }^{1}$

Richard L. Wiseman memberikan definisi komunikasi sebagai proses yang melibatkan pertukaran pesan dan penciptaan makna. ${ }^{2}$ Definisi ini memberikan pengertian bahwa komunikasi efektif apabila orang tersebut menafsirkan pesan yang sama seperti apa yang disampaikan oleh komunikator. Komunikasi efektif apabila mampu meminimalkan keslasahpahaman.

Onong Uhcjana Effendy Komunikasi adalah proses penyampaian pesan dalam bentuk lambing bermakna sebagai paduan pikiran dan perasaan berupa ide, informasi, kepercayaan, harapan, imbauan dan sebagainya yang dilakukan seseorang kepada orang lain baik langsung ataupun tatap muka maupun tak langsung melalui media dengan tujuan mengubah sikap, pandangan atau perilaku. ${ }^{3}$

Komunikasi pembelajaran dapat efektif jika dilakukan dengan memenuhi elemen daya tarik, pemahaman,

\footnotetext{
2 Richard L. Wiseman, Intercultural Communication Theory, (California State University, Fullerton, 1995), hlm 15

3 Onong Suhcjana Effendy, Kamus Komunikasi, Bandung : Mandar Maju,1989), hlm 60
} 
penerimaan, keterlibatan, dan keyakinan ${ }^{4}$. Lima elemen ini dapat dilakukan ketika penyampaian pesan dilakukan secara tatap muka langsung. Namun, ketika masa pandemi COVID-19 yang menerapkan pembelajaran jarak jauh berbasis internet, lima elemen ini dalam penerapannya menemui hambatan karena ruang gerak komunikator (guru) dan komunikasn (siswa) yang terbatas dalam pembelajaran daring. Pembelajaran daring yaitu proses transformasi pengetahuan dalam pembelajaran yang dilakukan dengan sistem penyebaran materi ajar secara terbuka dengan media pembelajaran berbasis jaringan internet yang kuat untuk melakukan interaksi pada saat proses pembelajaran berlangsung. Kelancaran pembelajaran daring ditunjang dengan adanya jaringan internet yang kuat, karena tanpa adanya jaringan internet yang kuat, maka pengajar dan peserta didik tidak dapat melangsungkan kegiatan belajar mengajar dengan baik ${ }^{6}$.

Dari pengertian komunikasi sebagaimana diuraikan di atas, tampak adanya sejumlah unsur-unsur komunikai yang dicakup dan merupakan terjadinya suatu proses komunikasi. Berikut unsur usur komunikasi adalah;

Pertama, Komunikator, sering disebut dengan pengirim pesan, sumber (source) dan pembuat atau pengirim

\footnotetext{
4 Basori Basori, "Efektifitas Komunikasi Pembelajaran Online Dengan Menggunakan Media E-Learning Pada Perkuliahan Body Otomotif," Jurnal Ilmiah Pendidikan Teknik Dan Kejuruan 7 , no. 2 (2017): 30.

${ }^{5}$ Novita Arnesti and Abdul Hamid, "Penggunaan Media Pembelajaran Online-Offline Dan Komunikasi Interpersonal Terhadap Hasil Belajar
}

informasi. Dilihat dari jumlahnya, komunikator terdiri dari satu orang, banyak orang dan massa. Jika harus menunjuk pada lebih dari satu orang komunikator bisa berarti kelompok seperti partai politik, organisasi atau lembaga dan media massa seperti surat kabar, radio, televisi, majalah, tabloid, internet. ${ }^{7}$

Kedua, Pesan, yang dimaksud dalam proses komunikasi adalah sesuatu yang disampaikan pengirim kepada penerima. Pesan dapat disampaikan dengan cara tatap muka atau melalui media komunikasi. Isinya dapat berupa ilmu pengetahuan, hiburan, informasi, nasehat, atau propaganda.

Dalam bahasa inggris biasanya diterjemahkan dengan kata message, content atau information. Pesan bisa dilihat dari beberapa segi diantaranya seperti cara penyampaian pesan dapat melalui lisan, face to face, langsung menggunakan media dan saluran lainnya. Selain itu dari bentuk bentuk pesan seperti (Informatif) bersifat memberian keterangan keterangan faktafakta, kemudian komunikan mengambil keputusan. (Persuasif) berisikan bujukan, yaitu membangkitkan pengertian dan kesadaran manusia bahwa apa yang disampaikan akan memberikan perubahan sikap, tetapi berubahnya atas kehendak sendiri bukan dipaksakan. (Koersif) penyampaian pesan yang bersifat memaksa

Bahasa Inggris," Jurnal Teknologi Informasi \& Komunikasi Dalam Pendidikan 2, no. 1 (2015): 88.

6 Hakiman, "Pembelajaran Daring," accessed December 27, 2020, https://iainsurakarta.ac.id/\%EF\%BB\%BFpembelajarandaring.

7 Nurudin, Ilmu Komunikasi Ilmiah dan Populer (Jakarta:PT RAJAGRAFINDO PERSADA, 2017) hlm 44 
dan dengan menggunakan sanksi-sanksi apabila tidak dilaksankan. ${ }^{8}$

Ketiga, Media, adalah alat yang digunakan untuk memindahkan pesan dari sumber kepada penerima. Terdapat beberapa pendapat mengenai saluran media misalna dalam komunikasi antarpribadi panca indra dianggap sebagai media komunikasi. Selain indra manusia, saluran komunikasi dapat disebut seperti telepon, surat, telegram yang digolongkan sebagai media komunikasi antarpribadi. Dengan demikian media adalah alat bantu untuk memindahkan pesan dari komunikator kepada penerima pesan. ${ }^{9}$

Keempat, Komunikan, adalah pihak yang menjadi sasaran pesan yang dikirim oleh sumber. Penerima bisa terdiri dari satu orang atau lebih. Dalam proses komunikasi telah dipahami bahwa keberadaan penerima adalah akibat karena adanya sumber. Tidak ada penerima jika tidak ada sumber.

Adanya kominikan menjadi elemen penting dalam proses komunikasi. Karena yang menjadi sasaran dari komunikasi. Jika suatu pesan tidak diterima oleh komunikan akan menimbulkan berbagai macam masalah. Karena itu, mengetahui dan memahami karakteristik komunikan merupakan suatu peluang untuk mencapai keberhasilan komunikasi.

Kelima, Efek, Pengaruh atau efek adalah perbedaan antara apa yng dipikirkan, dirasakan dan dilakukan oleh penerima sebelum dan sesudah menerima pesan. Pengaruh ini dapat terjadi pada

8 Nurdin dkk, Pengantar Ilmu Komunikasi,..., hlm.107

${ }^{9}$ Nurudin, Ilmu Komunikasi,..., hlm 48 pengetahuan, sikap, tingkah laku seseorang. Pengaruh dapat terjadi dalam bentuk perubahan pengetahuan (knowledge), sikap (attitude), dan perilaku (behavior).

Dalam komunikasi atarpribadi dan kelompok pengaruh dapat diamati secara langsung, misalnya penerima terlihat gembira setelah mendengar cerita lucu dari komunikator. Namun dalam komunikasi massa, pegaruh tidak dapat dengan mudah diketahui. Selain karena sifat massa tersebar, juga sulit dimonitor pada tingkat mana pengaruh tersebut terjadi. ${ }^{10}$

Keenam, Umpan balik, adalah salah satu bentuk daripada pengaruh yang berasal dari penerima. Namun, umpan balik juga berasal dari unsur lain seperti pesan dan media, meski pesan belum sampai pada penerima. Misalya sebuah konsep surat yang memerlukan perubahan sebelum dikirim atau alat-alat yang digunakan untuk menyampaikan pesan mengalami gangguan sebelum sampai ke tujuan. Hal tersebut terjadi tanggapan balik yang diterima oleh sumber. Efek dapat dilihat dari (personal opinion) yaitu sikap dan pendapat seseorang terhadap sesuatu masalah tertentu, (public opinion) yaitu penilaian sosial mengenai sesuatu hal yang penting dan berarti atas dasar pertukaran pikiran yang dilakukan individu secara sadar dan rasional serta (majority opinion) adalah pendapat sebagian besar dari public atau masyarakat. ${ }^{11}$

10 Nurdin dkk, Pengantar Ilmu Komunikasi,..., hlm.112

${ }^{11}$ Nurdin dkk, Pengantar Ilmu Komunikasi,..., hlm.112-113. 


\section{Gaya Komunikasi}

Gaya Komunikasi adalah perilaku komunikasi yang dilakukan seseorang dalam suatu organisasi yang bertujuan untuk mendapatkan feedback dari orang lain terhadap pesan organisasional yang disampaikan. $^{12}$

Dari definisi di atas, dapat dijelaskan bahwa gaya komunikasi merupakan seperangkat perilaku antar pribadi yang terspesialisasi yang digunakan dalam suatu situasi tertentu. Masing-masing gaya komunikasi terdiri dari sekumpulan perilaku komunikasi yang dipakai untuk mendapatkan respons atau tanggapan tertentu dalam situasi tertentu pula. Kesesuaian dari satu gaya komunikasi yang digunakan bergantung pula pada maksud si pengirim dan harapan dari penerima.Untuk dapat memahami terkait gaya komunikasi terlebih dahulu akan dibahas proses komunikasi dan macammacam gaya komunikasi.

Dalam Buku Teori Komunikasi yang disusun oleh S. Djuarsa Sendjaja, terdapat enam gaya komunikasi yaitu the controlling style, the equalitarian style, the structuring style, the dynamic style, the relingquishing style dan the withdrawal style, dengan penjelasan sebagai berikut, ${ }^{13}$

Pertama, The Controling Style. Adalah Gaya Komunikasi yang bersifat mengendalikan ini, ditandai dengan adanya adanya satu kehendak atau maksud untuk membatasi, memaksa dan mengatur perilaku, pikiran dan tanggapan orang lain. Orang - orang yang menggunakan gaya

12 S. Djuarsa Sendjaja,dkk,Pengantar Ilmu Komunikasi (Jakarta,Universitas Terbuka,1996) hlm 7 komunikasi ini dikenal dengan nama komunikator satu arah atau one way communicators. Para komunikator satu arah tersebut tidak khawatir dengan pandangan negative orang lain, tetapi justru berusaha menggunakan kewenangan dan kekuasaan untuk memaksa orang lain mematuhi pandangan-pandangannya.

Pesan-pesan yang berasal dari komunikator satu arah ini, tidak berusaha menjual gagasan agar dibicarakan bersama, namun lebih pada usaha menjelaskan kepada orang lain apa yang dilakukannya. The Controlling style of communications ini sering dipakai untuk mempersuasi orang lain supaya bekerja dan bertindak efektif dan pada umumnya dalam bentuk kritik. Namun demikian gaya komunikasi yang bersifat mengendalikan ini tidak jarang bernada negatif sehingga menyebabkan orang lain memberi respon atau tanggapan yang negative pula.

Kedua, The Equalitarian Style. Aspek penting gaya komunikasi ini ialah adanya landasan kesamaan. The Equalitarian style of communications ini ditandai dengan berlakunya arus penyebaran pesan-pesan verbal secara lisan maupun yang bersifat dua arah (no way traffic of communication). Dalam gaya komunikasi ini, tindak komunikasi yang dilakukan secara terbuka. Artinya, setiap anggota organisasi dapat mengungkapkan gagasan ataupun pendapat dalam suasana yang rileks santai dan informal. Dalam suasana yang demikian, memungkinkan

13 S.Djuarsa Sendjaja,dkk,Pengantar Ilmu Komunikasi(Jakarta,Universitas Terbuka,1996) hlm 143-145 
setiap anggota organisasi mencapai kesepakatan dan pengertian bersama.

Orang-orang yang menggunakan gaya komunikasi yang bermakna kesamaan ini, adalah orang-orang yang memiliki sikap kepedulian yang tinggi serta kemampuan membina hubungan baik dengan orang lain, baik dalam konteks pribadi maupun dalam lingkup hubungan kerja. The equalitarian style ini akan lebih memudahkan tindak komunikasi dalam organisasi, sebab gaya ini efektif dalam memelihara empati dan kerjasama, khususnya dalam situasi untuk mengambil keputusan terhadap suatu permasalahan yang kompleks. Gaya komunikasi ini pula yang menjamin berlangsungnya tindak berbagi informasi di antara para anggota dalam suatu organisasi..

Ketiga, The Structuring Style. Gaya Komunikasi yang terstruktur ini, memanfaatkan pesan-pesan verbal secara tertulis maupun lisan guna memantapkan perintah yang harus dilaksanakan, penjadwalan tugas dan pekerjaan serta struktur organisasi. Pengirim pesan lebih memberi perhatian kepada keinginan untuk mempengaruhi orang lain dengan jalan berbagi informasi tentang tujuan organisasi, jadwal kerja, aturan dan prosedur yang berlaku dalam organisasi tersebut.

Keempat, The Dynamic Style. Gaya komunikasi yang dinamis ini memiliki kecenderungan agresif, karena pengirim pesan atau sender memahami bahwa lingkungan pekerjaannya berorientasi pada tindakan (action-oriented). The dynamic style of communications ini sering dipakai oleh para juru kampanye ataupun supervisor yang membawahi para wiraniaga (salesman atau saleswomes).

Tujuan utama gaya komunikasi yang agresif ini adalah menstimulasi atau merangsang pekerja pegawai untuk bekerja dengan lebih cepat dan lebih baik. Gaya komunikasi ini cukup efektif digunakan dalam mengatasi persoalan-persoalan yang bersifat kritis namun dengan persyaratan bahwa pegawai atau bawahan mempunyai kemampuan yang cukup untuk mengatasi masalah yang kritis tersebut.

Kelima, The Relinquishing Style. Gaya komunikasi ini lebih mencerminkan kesediaan untuk menerima saran, pendapat ataupun gagasan orang lain, daripada keinginan untuk memberi perintah meskipun pengirim pesan mempunyai hak untuk memberi perintah dan mengontrol orang lain.

Pesan-pesan dalam gaya komunikasi ini akan efektif ketika pengirim pesan atau sender sedang bekerjasama dengan orangorang yang berpengetahuan atas semua tugas atau pekerjaan yang dibebankanya.

Keenam, The Withdrawal Style. Akibat yang muncul jika gaya ini digunakan adalah melemahnya tindak komunikasi, artinya ada keinginan dari orang-orang yang memakai gaya ini untuk berkomunikasi dengan orang lain, karena ada beberapa persoalan ataupun kesulitan antar pribadi yang dihadapi oleh orangorang tersebut.

\section{Metode Penelitian}

Metode penelitian yang dipakai dalam sebuah penelitian memiliki pengaruh yang sangat besar terhadap hasil penelitian. Penggunaan metode penelitian 
yang sesuai dan relevan akan memungkinkan mendapat hasil penelitian yang valid. Atas pertimbangan tersebut peneliti memilih pendekatan Kualitatif.

Penelitian ini menggunakan jenis penelitian kualitatif, dengan dasar pertimbangan (a) penelitian ini bertujuan untuk memahami dan mendeskripsikan data, mengembangkan konsep, serta menginterpretasikan data yang diperoleh dari lapangan. Penelitian ini merupakan penelitian deskriptif kualitatif, karena dilakukan untuk mencari data, fakta, penggambaran/ keadaan dan sejauhmana menjelaskan secara deskriptif yang bertujuan untuk menggali fakta yang bersangkutan tentang Gaya Komunikasi Model Profesional SZ Management Surabaya.(b) memberikan peluang dalam mengkaji fenomena secara menyeluruh dan kronologis sebagai suatu kesatuan yang tidak terpisahkan karena tindakan yang terjadi dalam sebuah Gaya Komunikasi Model Profesional Sz Management Surabaya bukanlah tindakan yang diakibatkan oleh satu faktor juga akan tetapi telah melibatkan sekian banyak faktor yang saling terkait.

Berdasarkan uraian di atas adalah bahwa the equalitarian style of communication merupakan gaya komunikasi yang ideal. Sementara gaya komunikasi lainnya : structuring, dynamic dan reliquinshing dapat digunakan secara strategis untuk menghasilkan efek yang bermanfaat bagi organisasi. Dan dua gaya komunikasi terakhir : controlling dan withdrawal mempunyai kecenderungan menghalangi berlangsungnya interaksi yang bermanfaat serta produktif.
Dengan demikian terdapat komunikasi verbal dan non verbal. Komunikasi Verbal adalah Bentuk komunikasi yang menggunakan kata-kata, baik lisan maupun tulisan. Bahasa adalah bagian terpenting dalam komunikasi verbal. Melalui simbol dan kode-kode tertentu.

Sedangkan Komunikasi Nonverbal adalah Setiap informasi atau emosi dikomunikasikan tanpa menggunakan kata-kata atau nonlinguistik. Komunikasi nonverbal adalah penting, sebab dalam aktivitas yang dilakukan mempunyai makna jauh lebih penting dari yang diucapkan. Salah satu dari beberapa alasan yang dikemukakan oleh Richard L. Weaver II (1993) bahwa kata-kata pada umumnya memicu salah satu sekumpulan alat indra seperti pendengaran, sedangkan komunikasi nonverbal dapat memicu sejumlah alat indra seperti penglihatan, penciuman, perasaan, untuk menyebutkan beberapa. Dengan sejumlah alat indra seseorang akan merespon isyarat-isyarat nonverbal secara emosional, sedangkan reaksinya ada kata-kata yang lebih bersifat rasional.

\section{Hasil dan Pembahasan}

\section{Profil SZ Management Surabaya}

Berawal dari Kak Suci Agustina Lestari yang sejak berusia 14 tahun sebagai penggemar trend fashion mengamati bahwa di era saat ini perkembangan dunia fashion semakin meningkat terutama di Indonesia yang telah menduduki peringkat pertama di bidang trend fashion untuk kalangan wanita. Sehingga, lahirlah beberapa desaigner yang merancang model 
mode busana serta banyak pula produk produk fashion yang dipasarkan di setiap toko-toko dengan mode yang bermacammacam khususnya di Kota Surabaya.

Dalam memasarkan produk fashion yang bermacam-macam tersebut, Seorang Designer selalu meminta Seorang Model atau Peragawati Untuk memperagakan busananya di setiap Event dengan tujuan agar memberikan ketertarikan kepada konsumen. Pada tahun 2004, Kak Suci Agustina Lestari yang kini menjadi Founder dari SZ Management Surabaya terisnpirasi dengan dunia fashion, Semenjak lulus dari SMA sangat menekuni dunia tersebut, dan menyukai untuk mengikuti lomba fashion model, lomba Make Up, serta mengikuti pelatihanpelatihan menjadi desaigner di bidang fashion.

Namun, karena oleh Ayahnya diharuskan untuk fokus dengan pendidikannya setelah menyelesaikan Pendidikan tingkat SLTA di Medan, Sehingga setelah lulus Ia focus untuk melanjutkan Perkuliahan di D3 Akuntansi di (IBMI) International Bisnis Management Indonesia. Setelah menyelesaikan pendidikan D3 pada tahun 2005 Kak Suci mendapat dua pilihan dari Ayahnya untuk melanjutkan pendidikannya kembali S1 antara di Surabaya dan di Bandung. Dari pilihan tersebut Kak Suci lebih memilih di Kota Surabaya karena di sana lebih menantang dibandingkan di Bandung.

Setelah menentukan pilihan mencari Ilmu di Kota Surabaya, Kak Suci melanjutkan Pendidikan S1 Ilmu Komunikasi di UNITOMO Surabaya.
Selama di Surabaya banyak kegiatan kegiatan yang diikutinya salah satunya komunitas Hijabers di Surabaya. Disitulah Kak Suci mampu mengembangkan passionnya kembali seperti fashion modeling, make up serta belajar bersama para designer fashion di Kota Surabaya. Hingga tahun 2012 Kak Suci masih bergabung dengan komunitas Hijabers tersebut yakni Komunitas Azura Muslim Surabaya.

Pada Awal tahun 2013, Kak Suci memiliki Inovasi untuk membuka Sekolah Modeling Khusus wanita berhijab di Kota Surabaya. Inovasi ini dikarenakan setelah terinspirasi bergabung di komunitas Azura Model Surabaya melihat banyak wanita wanita berhijab, namun akan lebih indah dan cantik jika mereka mampu menerapkan dunia fashion pada dirinya. Saat itu kak suci mengajak beberapa rekan rekannya dari Azura Muslim Surabaya untuk berinovasi membuat sekolah modeling berhijab, secara garis besar pendapat tersebut banyak menarik perhatian para anggota.

Di Kota Surabaya memang sangatlah banyak sekolah modeling, akan tetapi ratarata diikuti oleh wanita yang tidak berhijab. Sehingga inilah inovasi Kak Suci untuk mendirikan Sekolah Modeling khusus wanita muslim di Kota Surabaya. Tepat di awal bulan Febuari 2013, Kak Suci melahirkan anaknya yang kedua yaitu perempuan bernama Zahra. Ia berharap kelak anaknya dapat melanjutkan sekolah yang didirikan oleh Sang Ibu. Sehingga Sekolah tersebut dinamakan SZ Model Muslimah Surabaya. SZ yang berkepanjangan dari Suci dan Zahra, 
Sedangkan Model Muslimah merupakan sekolah modeling yang diperuntukkan kepada para remaja muslimah. Pada Akhir Febuari Sekolah tersebut telah terbentuk dan dimulailah kelas bersama dengan para team SZ Muslim Management.

Di mulai tahun 2014, sebutan nama SZ Model Muslimah telah diganti menjadi SZ Management Surabaya. Dikarenakan, selain SZ menjadi sekolah modeling juga menjadi tempat model-model muslimah professional yang mampu bekerjasama dengan para designer khususnya di Kota Surabaya. Sekolah Modeling ini dilaksanakan selama 3 bulan 15 kali pertemuan. Kelas dilaksanakan setiap hari Minggu di Kantor SZ Management yang beralamatkan di jalan Sidodermo II No 363 Surabaya.

Adapun materi yang didapatkan oleh para siswanya diantaranya materi catwalk, materi public speaking, materi mambaca Al-Qur'an, materi, materi make up serta materi photoseshion. Hingga saat ini, peminat remaja putri muslimah yang ada di Kota Surabaya semakin meningkat untuk bergabung di kelas SZ Management Surabaya. Setiap kelas terdiri maksimal 20 siswa, dan saat ini telah masuk di Batch 10 kelas SZ Management Surabaya. Telah terdapat ratusan alumni SZ Management Surabaya yang telah menyelesaikan sekolah modeling.

Di tahun 2015, SZ Management memberikan kelas motivasi dan event tour setiap akhir kelas bersama dengan siswasiswanya. Hal ini dikarenakan, Secara umum persyaratan menjadi seorang model atau peragawati memang yang paling utama adalah tinggi badan. Namun, masih terdapat beberapa siswa yang menginginkan untuk menjadi seorang model namun masih kurang memenuhi kriteria. Sehingga kelas motivasi ini juga mengarahkan kepada para siswanya untuk bisa menekuni bidang lain, baik menekuni make up sehingga dapat membuat bisnis make up kelak, ilmu fotografi sehingga mampu menjadi sosok fotografer maupun public speaking sehingga mampu menjadi seorang mc atau presenter handal kelak. Adapun event tour, dengan tujuan agar tetap terjalin tali silaturahmi di seluruh keluaga bear SZ Management Surabaya.

Di tahun 2016, SZ Management Surabaya membuka tambahan kelas Bahasa Ingris yang bekerjasama dengan English Yong di Kampung Inggris Pare Kediri. Tujuan adanya kelas ini dikarenakan, bahasa inggris merupakan bahasa internasional, sehingga sangat penting digunakan khususnya dalam berkomunikasi kelak melamar pekerjaan mapun dalam setiap persaingan kompetisi.Sehingga pada tahun 2016, SZ menambahkan kelas bahasa inggris khususnya di bidang speaking kepada para siswanya.

Di tahun 2017, SZ Management telah menghasilkan beberapa model- model professional. Terdapat beberapa alumni SZ Management Surabaya yang telah menoehkan pretasinya hingga di tingkat nasional. Sehingga, nama SZ Management Surabaya telah dikenal oleh para desaigner dan fotografer. Dalam setiap acara festival fashion SZ Management selalu di undang untuk menampilkan para model-modelnya menggunakan busana karya desaigner. Hingga saat ini telah terdapat puluhan 
designer yang telah mempercayai model

SZ Management sebagai model peraga busana karya para designer.

Gaya Komunikasi Model

Professional SZ Management adalah;

\section{Tampil Fashionable sebagai Gaya} Komunikasi secara Nonverbal

Profesi sebagai Model merupakan sebuah profesi yang menjual jasa, dalam aktivitasnya seorang model menjadi mediator antara designer dengan konsumen. Keberadaan model dibutuhkan untuk berperan sebagai pelaku yang mampu megkomunikasikan busana kepada para konsumen. Sebagai Model Profesional di SZ Management Surabaya yang telah menyelesaikan pendidikan modelling selama tiga bulan akan menghadapi tantangan dalam berkarir seperti menjalin hubungan dan melakukan kerjasama dengan para designer. Seorang model setelah menyelesaikan pendidikan modelling tentunya memiliki penguasaan dalam melakukan (catwalk) berjalan di atas panggung dengan menggunakan berbagai busana, memiliki kekayaan gaya karakter agar mampu memberikan kemasan menarik dalam menjual sebuahproduct fashion, kecakapan dalam (public speaking) mampu berbicara dengan baik dan mnunjukkan kecerdasannya saat mengikuti kompetisi, memperagakan berbagai bentuk busana di atas panggung, melakukan kegiatan photoshoot, melakukan sebuah interaksi dengan pihak lain serta keterampilan dalam (make up) yaitu merias wajah. Seorang model professional harus dapat menggunakan make up secara natural maupun glamour ketika mengikuti berbagai acara yang berbeda- beda.

Selain dari kecerdasan di dunia modelling syarat terpenting yang harus dimiliki adalah postur tubuh yang ideal. Secantik dan sepintar apapun seorang model jika tubuh tidak ideal sangat sulit terjun dan berprofesi di dunia model. Karena hal ini sangat berpengaruh dalam memberikan kemasan yang menarik. Selain itu, Pentingnya penampilan bagi seorang model setiap busana yang dikenakan oleh orang dapat memberikan penilaian terhadap orang tersebut. Jika seseorang berpenampilan rapi dan modis, akan dinilai menjadi orang yang cerdas, rapi dan modern. Adapun penggunaan bahasa yang perlu sangat diperhatikan terutama ketika berkomunikasi dengan berbagai pihak. Seseorang dapat dikatakan mampu beriteraksi dengan baik jika pandai dalam menggunakan bahasa karena bahasa menunjukkan penilaian diri seseorang dalam etika kesopanan. Apabila model professional selain postur tubuh ideal, fashionable dan pandai dalam bergaul akan lebih popular jika model memiliki prestasi baikdi lingkup akademik maupun non akademik. Seorang model yang cerdas akan memiliki jam terbang yang cukup tinggi dibandingkan model yang hanya mengandalkan kecantikan di bagian fisik saja.

Tidak dapat terlewatkan jika model lupa dalam menjaga etika keprofesionalan ketika melakukan kerjasama dengan berbagai pihak. 
Meskipun model sangat dipandang sempurna di depan public namun tanpa adanya dukungan dari designer, make up artis maupun fotografer seorang model tidak dapat melakukan apapun hingga sepopuler mungkin. Tentu, sikap kedisiplinan, saling menghormati dan menghargai serta mampu menjalin kerjasama dengan baik dan saling memberikan keuntungan diantara kedua pihak dapat memberikan nilai postif dari model tersebut.

Memiliki kekayaan karakter menjadi pilihan dan sorotan utama designer maupun para fotografer. Dengan kayanya karakter dalam berpose dapat dengan mudah mengekspresikan bentuk busana yang dikenakan dan situasi yang terjadi sehingga memberikan kemasan menarik dalammempromosikan sebuah produk. Disitulah menjadi model yang dapat meyakinkan public untuk memiliki keingininan dalam membeli suatu product.

Dalam menjalin kerjasama seorang model melakukan suatu kegiatan komunikasi. Sebagaimana komunikasi adalah suatu Interaksi yang dilakukan oleh dua orang atau lebih yang dilakukan secara lisan, tulisan maupun penggunaan gesture tubuh dengan tujuan agar tercipta sebuah makna untuk menjalin hubungan yang memberikan kepuasan di antara kedua pihak.

Terjadinya sebuah tindakan komunikasi apabila terdapat beberapa unsur diantaranya seperti komunikator atau orang yang memberi sebuah pesan, komunikan atau orang yang menerima pesan, pesan yang disampaikan, media dan umpan balik antara komunikan ke komunikator. Kesuksesan dalam melakukan aktivitas komunikasi dalam penelitian ini terlihat ketika seorang model (komunikator) memberikan pesan kepada para designer (komunikan) secara langsung maupun melalui media yang dilakukan secara verbal ataupun nonverbal sehingga menciptakan sebuah makna yang diterima oleh para designer dan terjadilan keputusan penerimaan diantara keduanya.

Pesan yang disampaikan seorang model kepada para designer secara langsung dapat dilakukan baik dengan lisan, tulisan maupun gesture tubuh. Secara lisan seorang model melakukan aktivitas komunikasi saat melakukan wawancara dan bertemu secara langsung dengan para designer. Adapun melalui gesture tubuh dapat dilihat dari posture tubuh, busana atau penampilan, penggunaan alat bahasa, kecerdasan maupun prestasi, etika berkomunikasi serta ekspresi wajah saat tampil di depan panggung maupun di depan kamera. Sedangkan pesan melalui media seperti beberapa postingan foto kegiatan modeling seperti foto endorse dengan busana-busana karya designer dan video saat melakukan catwalk di panggung kehormatan. sehingga berbagai bentuk pesan tersebut dapat diterima secara langsung oleh para designer.

Tujuan komunikator menyampaikan pesan tentu agar keinginan dalammenyampaikan sebuah 
sumber informasi atau sebuah pesan dapat terpenuhi. Komunikan menjadi elemen penting dalam proses komunikasi. Karena yang menjadi sasaran dari komunikasi. Jika suatu pesan tidak diterima oleh komunikan akan menimbulkan berbagai macam masalah. Karena itu, mengetahui dan memahami karakteristik komunikan merupakan suatu peluang untuk mencapai keberhasilan komunikasi. Sebagai Seorang Model Profesional seelum memutuskan untuk berinteraksi dengan para designer juga harus memahami katakter dan lingkungan dari para designer tersebut. Ketika bertemu dengan designer yang cukup terkenal, seorang model dituntut agar selalu berbicara yang sopan dan santun, berpenampilan menarik saat bertemu dengan para designer tersebut serta selalu menghormati dan mematuhi sesuatu peraturan. Dalam hal tersebut, tentu seorang komunikan akan merasa nyaman terhadap komunikator. Sehingga segera memberikan respon dan umpan balik yang posditif kepada komunikator.

Setiap aktivitas komunikasi akan memiliki fungsi masing-masing sesuai bentuk komunikasi yang dilakukan. Terdapat empat fungsi komunikasi diantaranya fungsi komunikasi sosial, fungsi komunikasi ekspresif, fungsi komunikasi ritual dan fungsi komunikasi instrumental. Seorang Model Profesional melakukan interaksi kepada para designer yang dilakukan secara lisan maupun menggunakan geture tubuh sehingga menghasilkan sebuah makna dan terjadi keputusan penerimaan termasuk tindakan komunikasi sebagai fungsi komunikasi Instrumental.

Fungsi komunikasi Instrumental merupakan tindakan komunikasi yang yang bertujuan memberitahukan suatu informasi yang bersifat persuaif. Dapat diketahui bahwa pembicara menginginkan pendengarnya mempercayai tentang fakta dan informasi yang disampaikan benar. Hal ini jika ditunjukkan dalam suatu penelitian tentang gaya komunikasi model professional SZ Management Surabaya ketika melakukan tindakan komunikasi yang dilakukan secara verbal dan nonverbal mampu menyampaikan informasi dengan baik dan memberikan informasi dengan benar sesuai yang terjadi. Informasi atau pesan yang telah diberikan seorang model kepada para designer dapat memberikan respon postif dari para designer sehingga dapat lebih erat dalam menjalin hubungan diantara keduanya.

Tindakan komunikasi yang dilakukan oleh setiap orang memiliki gayayang berbeda beda termasuk model professional sz management Surabaya. Pengertian gaya komunikasi adalah perilaku seseorang dalam melakukan aktivitas komunikasi dengan tujuan untuk mendapatkan sebuah respon positif dari penerima pesan. Pada penelitian ini yaitu gaya komunikasi model professional SZ Management Surabaya memiliki salah satu dari enam macam gaya komunikasi yaitu salah 
satunya gaya komunikasi the relinquishing style yaitu gaya komuikasi yang lebih mencerminkan kesediaan untuk menerima saran, pendapat ataupun gagasan orang lain daripada keinginan untuk memberi perintah meskipun pengirim pesan mempunyai hak untuk memberi perintah dan mengontrol orang lain.

Pesan-pesan dalam gaya komunikasi ini akan efektif ketika pengirim pesan atau sender sedang bekerjasama dengan orang-orang yang berpengetahuan atas semua tuga atau atau pekerjaan yang dibebankan. Sesuai yang dilakukan oleh model kepada para designer, seorang model sebagai pengirim pesan menyampaikan pesan secara verbal dan nonverbal kepada designer sehingga timbul sebuah makna yang dipahami oleh designer dan merespon pesan tersebut dan keduanya melakukan suatu interaksi atau hubungan dalam melakukan Kerjasama.

Terpilihnya sebagai model sangat membutuhkan usaha yang cukup besar, tidak hanya dimiliki setelah mengikuti pendidikan modeling di sekolah sekolah modelling. Setiap Model dapat disebut professional jika dapat menunjukkan penampilan yang fashionable baik di backstage maupundi frontstage. Tampil fashionable merupakan cara menunjukkan performance seseorang baik dari postur tubuh dan kesesuaian busana, asesoris maupun make up sedangkan fotogenic yakni kemampuan memilikiwajah unik yang bersahabat dengan kamera, Sehingga siapapun yang memiliki kemampuan wajah tersebut tentu selalu memiliki kecocokan dalam menggunakan buasana apapun.

2. Kemampuan Bicara dengan Bahasa Model sebagai Gaya Komunikasi secara Verbal

Komunikasi secara verbal merupakan komunikasi yang menggunakan lambing bahasa lisan atau bahasa tulisan. Bahasa merupakan bagian terpenting dalam komunikasi verbal. Melalui simbol dan kode- kode tertentu seseorang dapat mengirimkan pesan dengan orang lain secara lebih jelas. Terdapat tiga prinsip dari komunikasi nonverbal yakni interpretasi menciptakan makna, komunikasi adalah aturan yang terpadu dan penekananmemengaruhi makna.

Interpretasi menciptakan makna akan muncul dipengaruhi oleh komunikasi verbal. Hal ini dapat dipengaruhi oleh pengetahuan, latar belakang, kepentingan, tujuan berkomunikasi atau aspek psikologis setiap orang. Seperti yang dilakukan oleh para model profesional di SZ Management Surabaya yakni ketika designer telah mengamati keunggulan model melalui gesture tubuh, maka akan melakukan sebuah percakapan secara langsung untuk mengetahui kecerdasan dan etika pribadi model tersebut.

Dalam setiap kegiatan model SZ Management selalu mengatakan 'Terima kasih atas kepercayaannya, saya berusaha menampilkan sebaik mungkin dalam memperagakan busana 
anda.'’. Dari perkataan tersebut tecipta sebuah interpretasi oleh designer bahwa Model SZ Management Surabaya sangat menghormati dan menghargai para designer yang telah mempercayainya dan dengan kemampuan yang dimiliki akan melalukan penampilan yang terbaik dalam memperagakan beragai busana yang digunakannya.

Komunikasi adalah aturan yang terpadu berkaitan dengan pemahaman bersama terhadap makna komunikasi dan macam komunikasi yang covok atau tidak untuk berbagai situasi. Dalam melakukan tindakan komunikasi seorang komunikator maupun komunikan harus dapat mengikuti aturan yang tepat seperti kapan, bagaimana, dimana dan dengan siapa harus berbicara mengenai hal hal tertentu. Sebagaimana seorang model professional selalu berusaha menmpatkan posisinya dalam melakukan tindakan komunikasi. Ketika sedang melakukan wawancara dalam konteksformalitas maka seorang modelpun akan menggunakan bahasa Indonesia secara formal yang benar, sopan dan santun. Namun sebaliknya, ketika diacara santai misalnya setelah acara selesai, maka model professional juga sapat mengikuti cara berkomunikasi sesuai situai yang ada seperti bercanda atau membahas informasi lain akan tetapi tetap menjaga etika keprofesionalan seorang model professional.

Prinsip yang terakhir dari komunikasi verbal yaitu penekanan mempengaruhi makna yang merupakan sebuah kesepakatan umum komunitas. Hal ini dapat ditunjukkan ketika model professional menggunakan busana pengantin muslim glamour yang cukup mewah dan rok yang dikenakan sangat panjang dan lebar hingga menyapu lantai, tentu harus berhati hati dalam berajalan memperagakan busana. Desaigner memberikan ucapan kepada para model ketika akan tampil dengan kata,'Jalannya ya!'’. Menandakan bahwa untuk berjalan memperagakan busana seorang model harus memahami maksud perintah yang disampaikan yakni berhati-hati dan pelan pelan saat berjalan, kedua tangannyamemaerkan rok yang mewah sehingga terkesan jalannya sangat cantik dan balutan busana sangat menarik ketika diperagakan di atas panggung.

Selain memahami prinsip prinsip dari komunikasi secara verbal juga terdapat berbagai bentukucapan secara lisan dalam bentuk kata kata yang diucapkan oleh model professional SZ Management Surabaya dalam melakukan interaksi baik dengan rekan sejawat maupun ketika berinteraksidengan para designer.

Gaya komunikasi secara verbal melalui tulisan yang dilakukan oleh seorangmodel memiliki suatu ciri khas dibandingkan gaya komunikasi pihak lainnya. Melalui tulisan tersebut panggilan "sayang" menjadi suatu keakraban bagi seorang model dalam menjalin komunikasi dengan siapapun meskipun keduanya adalah memiliki kesamaan secara jenis kelamin. Ketika 
di pangggil dengan kata selain 'sayang', baik itu "'anda' maupun 'beliau' meskipun model tersebut telah memiliki segudang prestasi maka yang terjadi adalah suatu ketidaknyamanan dalam kegiatan komunikasi ataupun interaksi.

Sebagai fungsi dari teori interaksi simbolik memberikan perhatian pada cara - cara terhadap tindakan manusia bersatu dalam menentukan makna. Dalam melakukan setiap kegiatan komunikasi untuk mencapaihubungan yang lebih erat dapat dilakukan dengan cara yang berbedabeda. Sebagaimana dalam teori interaksi simbolik terjadinya interaksi antara komunikator dan komunikan jika terdapat suatu makna dari pesan yang disampaikan kemudian adanya tanggapan dari penerima pesan yang di tunjukkan kepada komunikator. Apabila seorang komunikan telah menerima pesan dan tidak terjadi tanggapan yang ditujukan kepada komunikator bukanlah sebuah interaksi antara kedua pihak melainkan terjadinya aktivitas komunikasi.

Dalam teori interaksi simbolik jenis - jenis komunikasi memang sangat terkait didalamnya. Komunikasi secara verbal dan nonverbal dalam suatu kegiatan interaksi antara kedua pihak dapat berfungsi untuk menciptakansebuah makna dari pesan yang tunjukkan oleh gambaran diri, pikiran maupun keinginan yang kuat dalam melakukan kegiatan interaksi. Teori interaksi simbolik berpegang bahwa individu membentuk makna melalui proses komunikasi.
Menurut Mead, terdapat tiga komponen penting dalam proses komuikasi untuk membentuk sebuah makna yang berasal dari masyarakat yakni pihak yang akan melakukan suatu interaksi, diri (self) yaitu dapat berakibat pada diri individu setelah pesan disampaikan kembali oleh komunikan berupa perasaan dan penilaian terhadap diri sendiri serta pikiran manusia (mind) merupakan perencanaan tindakan kedepan dalam penafsiran makna dari komunikan untuk menjalin interaksi lebih kuat agar tetap berkelanjutan hubungan kediu pihak dalam melakukan kegiatan komunikasi.

Tindakan model profesional dalam penelittian ini dan designer ketika melakukan kerjasama sangat releven dengan teori interaksi simbolik. Adanya pesan secara verbal dan non verbal dari komunikator telah ditunjukkan kepada komunikan sehingga tercipta sebuah makna dari komunikan. Makna yang telah diciptakan melalui pesan yang disampaikan tersebut kembali di tujukan kepada komunikator sehingga keduanya saling berinteraksi yang diawali dari simbol-simbol pesan untuk tercapai sebuah makna.

Memiliki profesi sebagai seorang model sangat erat untuk melakukan kerjasama dengan designer yaitu perancang busana. Kesuksesan dalam memasarkan produk busana akan sukses jika salah satunya dapat menjalin kerjasama dengan seorang model professional. Sebagai seorang model yang selalu diinginkan dan sangat dicari- cari oleh para designer ialah model yang 
memiliki kesempurnaan baik dari fisik maupun nonfisik

\section{Kesimpulan}

Gaya komunikasi yang dilakukan oleh Model Profesional SZ Management Surabaya melalui pendekatan Interaksi simbolik terdapat jenis - jenis gaya komunikasi yaitu secara verbal dan nonverbal. Kedua jenis - jenis gaya komunikasi tersebut saling berjalan secara bersamaan dan saling melengkapi. Pengaruh yang ditimbulkan dari masing masing komunikasi verbal maupun nonverbal tersebut sangat berhubungan.

Kata yang diucapkan seorang model tentu saja menimbulkan banyak arti, dari nada menyampaikan, ekspresi wajah, gerakan badan, tatapan wajah dan lain sebagainya. Adapun isyarat tubuh(gesture) juga menimbulkan banyak arti dari postur tubuh, penampilan, etika dan lain lain. Saat proses dalam melakukan tindakan interaksi, peneliti mengamati seorang model professional menunjukkan foto model sebagai bentuk simbol dengan berbagai kekayaan gaya kerakter. Selain itu, bertemu dengan designer secara langsung sehingga peneliti mengetahui terkait cara berbicara, postur tubuh serta penampilan dari seorang model dalam melakukaninteraksi.

\section{Daftar Pustaka}

Arikunto, Suharsimi,tt, Prosedur Penelitian Suatu Pendekatan Praktik, Jakarta: PT.Rineka Cipta.

$\begin{array}{lrr}\text { Aw, } & \text { Uranto ,2011, } & \text { Komunikasi } \\ \text { Antarpribad,Jakarta: } & \text { Universitas } \\ \text { Terbuka. } & \end{array}$

Bungin, Burhan, 2015, Komunikasi Pariwisata Tourism Communication Pemasaran dan Brand Destinasi, Jakarta: Prenadamedia Group.

Cangara, Hafied, 2004, Pengantar Ilmu Komunikasi, Jakarta: PT Raja GrafindoPersada.

C. A. Hickmann da Manford Kuhn, Group, and Economic Behavior, New York, 1956, dalam Littlejhon Dulbert, Biatna Tampubolon, 2007, Jurnal Analisis Faktor Gaya Kepemimpinan dan Faktor Etos Kerja Terhadap Kinerja Pegawai pada Organisasi yang telah menerapkan SNI 199001-2001,Yogyakarta

Deddy Mulyana, 2008, Ilmu Komunikasi Suatu Pengantar, Bandung: PT Remaja Rosdakarya.

Effendy, Onong Uchjana, 1999, Ilmu Komunikasi Teori dan Praktek, Bandung: Remaja Rostda Karya.

Jalaluddin Rakhmat, 1995, Metode Penelitian Komunikasi, Bandung: PT. RemajaRosdakarya.

H. Bleek, Reed, 1979, A. Taxonomi Of Consept in Communication, USA : HastingHause, Publiser Inc

Heinen, Renata, 1997, Panduan Model Semua yang perlu diketahui untuk menjadi model sukses, Jakarta:PT Pustaka Delapratasa.

Kriyyantono, Rachmat, 2009, Teknik PRaktis Riset Komunikasi, Jakarta: PT KencanaPersada.

Morisson,2014, Teori Komunikasi Individu Hingga Massa, Jakarta: Prenada media Group.

Nihayati, Laily, 2013, Karier TOP Sebagai Mode Fashion,Jakarta,PPM Management Nurdin, Ali dkk, Pengantar Ilmu Komunikasi, 2013, Surabaya :IAIN SA Press . 
Nurudin, 2017, Ilmu Komunikasi Ilmiah dan Populer, Jakarta: PT RAJAGRAF INDOPERSADA.

Ruslan, Rosady, 2003, Metode Penelitian Public Relations dan Komunikasi, Jakarta:PT. Raja Grafindo Persada.

Sanggarwati,Ratih, Kiat, 2013, Menjadi Model Profesional, Jakarta, PT GramediaPustaka Utama.

Sugiyono,Metode Penelitian Kuantitatif Kualitatif dan R\&D, Bandung: Alfabeta.

Wiseman, Richard L 1995, Intercultural Communication Theory, (California StateUniversity, Fullerton.

W. LittleJhon Sthepeen, \& Karen A.Foss, 2009, Teori Komunikasi, Jakarta: PT. SalembaHumanika.

William C. Himstreet Murlin Baty,1990, Bussines Communications: Principlesand Methods, Boston: Publishing Company. 